\title{
Flood of April and May 2008 in Northern Maine
}

The U.S. Geological Survey (USGS) Maine Water Science Center has worked with the Federal Emergency Management Agency (FEMA) for decades to document the magnitude and extent of major floods in Maine. A report describing the April/May $2008 \mathrm{flood}$ in northern Maine is an example of this cooperative relationship (Lombard, 2010). The documentation of peak stream elevations, peak streamflow magnitudes, and annual exceedance probabilities provides essential information for the delineation of flood plains and for flood-mitigation decisions by local, State, and Federal emergency management officials.

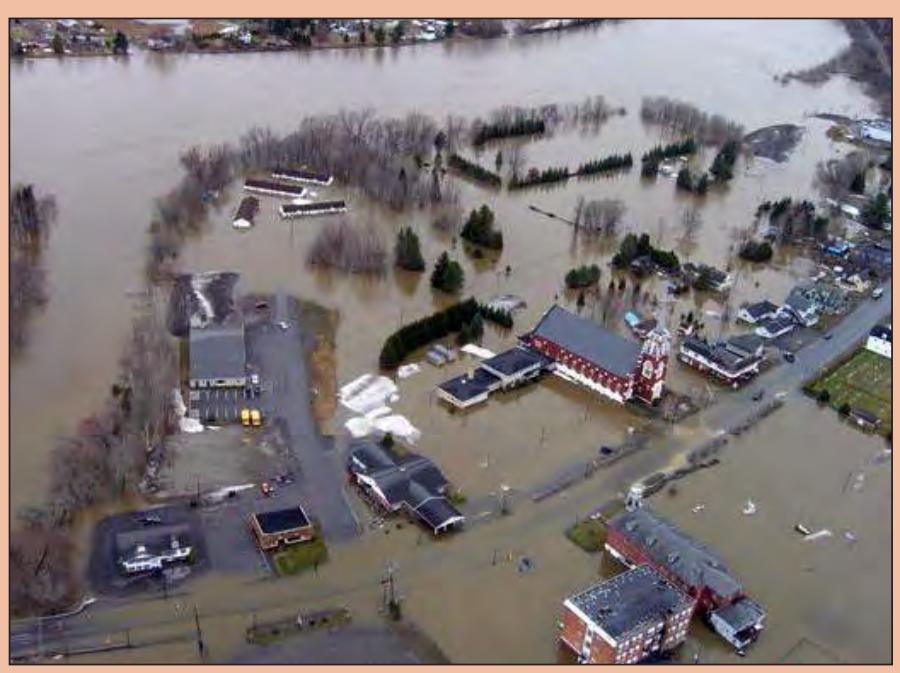

Fort Kent, Maine, on May 1, 2008. (Photograph courtesy of the Maine Department of Public Safety)

\section{Introduction}

Severe flooding occurred in Aroostook and Penobscot Counties in northern Maine between April 28 and May 1, 2008, and damage was extensive in the town of Fort Kent. Aroostook County was declared a Federal disaster area on May 9, and the declaration was expanded to include Penobscot County on May 16-qualifying the entire region for federal assistance.

Water in the St. John River peaked at 30.17 feet in Fort Kent ( 5 feet above flood stage), hit the low steel of the International Bridge connecting Fort Kent to New Brunswick, caused closure of international bridges in Fort Kent, Van Buren, and Hamlin and came within inches of the top of a 30-foot-high earthen dike constructed to protect the downtown area of Fort Kent. Longterm streamgages with 25 to 84 years of record on the Big Black, St. John, Allagash, Fish, and Aroostook Rivers recorded maximum streamflows for their respective periods of record.

Northern Maine experienced major floods in 1923, 1973, 1974, 1979, and 1983 (Maloney and Bartlett, 1991).
All of these floods were in late April or early May when heavy rain combined with snowmelt runoff.

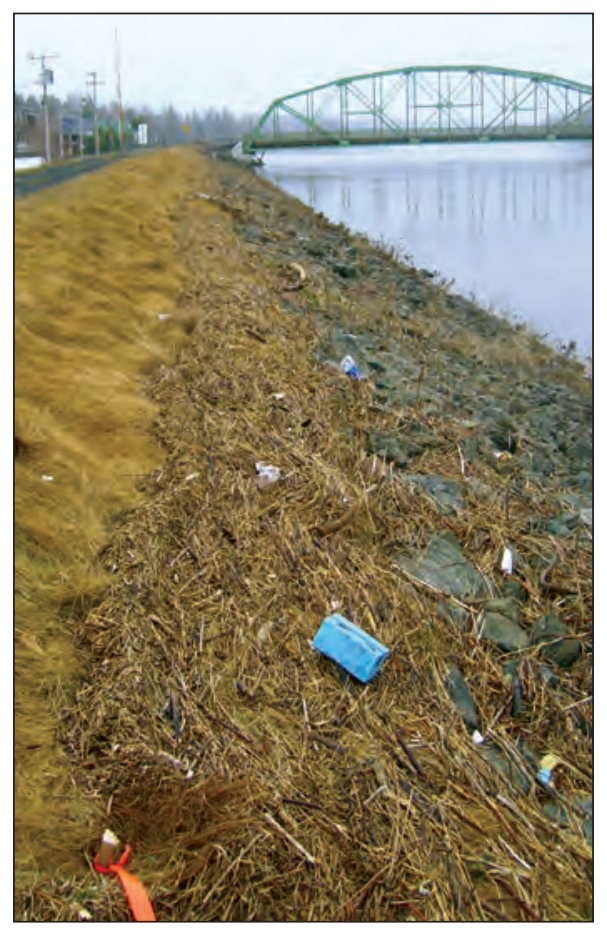

Flood debris line along St. John River dike in Fort Kent, Maine, on May 3, 2008. (Photograph by Laura Flight, U.S. Geological Survey)

\section{Antecedent Hydrologic Conditions and Storm Characteristics}

Areas of northern Maine received between 150 and 200 inches of snow during the winter of 2007-08, an aboveaverage amount for the region. From 40 to 70 inches of this snowpack (equivalent to 10 to 15 inches of water from snow) remained on the ground in mid-April (River Flow Advisory Commission, State of Maine, 2008). High air temperatures caused the water content of the snowpack to drop more than 8 inches between April 15 and 29, filling rivers and streams to capacity. In the week preceding the heavy rain, streamflows in the Fish and St. John Rivers were elevated, with annual exceedance probabilities between 50 and 10 percent (recurrence intervals between 2 and 10 years).

A low-pressure system developed in Pennsylvania on Monday, April 27, and the resulting storm moved into southern Maine by April 29. Rain continued through April 30, and rainfall totals ranged from 2 to 4 inches in northern Maine. 


\section{Peak Stream Elevations}

Seventy-five peak stream elevations were determined in Aroostook and Penobscot Counties following the April/ May 2008 flood. Peak stream elevations were determined using data from streamgages and by surveying highwater marks.

\section{Peak Streamflow Magnitudes and Exceedance Probabilities}

Peak streamflow magnitudes and exceedance probabilities were calculated for the April/May 2008 flood at 20

locations (fig. 1). Peak streamflows were determined from a rating curve (relation between streamflow and stream elevation at a streamgage) at 14 sites and by use of hydraulic models that were based on relations between streamflow and streamchannel geometry at 6 sites.

Streamflows observed during the spring 2008 flood had the lowest exceedance probabilities along Maine's northern border with Canada (fig. 1). The Allagash River near Allagash (USGS streamgage 01011000), the St. John River in Fort Kent (USGS streamgage 01014000), and Fish River at Fort Kent (USGS streamgage 01013500) all had flows with annual exceedance probabilities of less than 1 percent (recurrence intervals greater than 100 years).

\section{Selected References}

Lombard, P.J., 2010, Flood of April and May 2008 in northern Maine: U.S. Geological Survey Scientific Investigations Report 2010-5003, 17 p.

Maloney, T.J., and Bartlett, W.P., 1991, Maine floods and droughts, in Paulson, R.W., Roberts, R.S., and Moody, D.W., comps., National water summary 1988-89-Hydrologic events and floods and droughts: U.S. Geological Survey Water-Supply Paper 2375, p. 311-318.

National Weather Service, 2008, Climate data-Past weather and normals: Gray, Maine, National Weather Service Forecast Office, accessed May 21, 2008, at http://www.erh.noaa.gov/er/gyx/ climate_f6.shtml\#daily_hi_lo_precip_annual.

River Flow Advisory Commission, State of Maine, 2008, Maine cooperative snow survey: accessed August 1, 2008, at http://www.maine.gov/rfac/ rfac_snow.shtml.

\section{By Pamela J. Lombard}

For more information, please contact:

Robert Lent, Director

USGS Maine Water Science Center

196 Whitten Road

Augusta, Maine 04330

Telephone: (207) 622-8201

E-mail: dc_me@usgs.gov

Web site: $\overline{h t t p: / / m e . w a t e r . u s g s . g o v ~}$

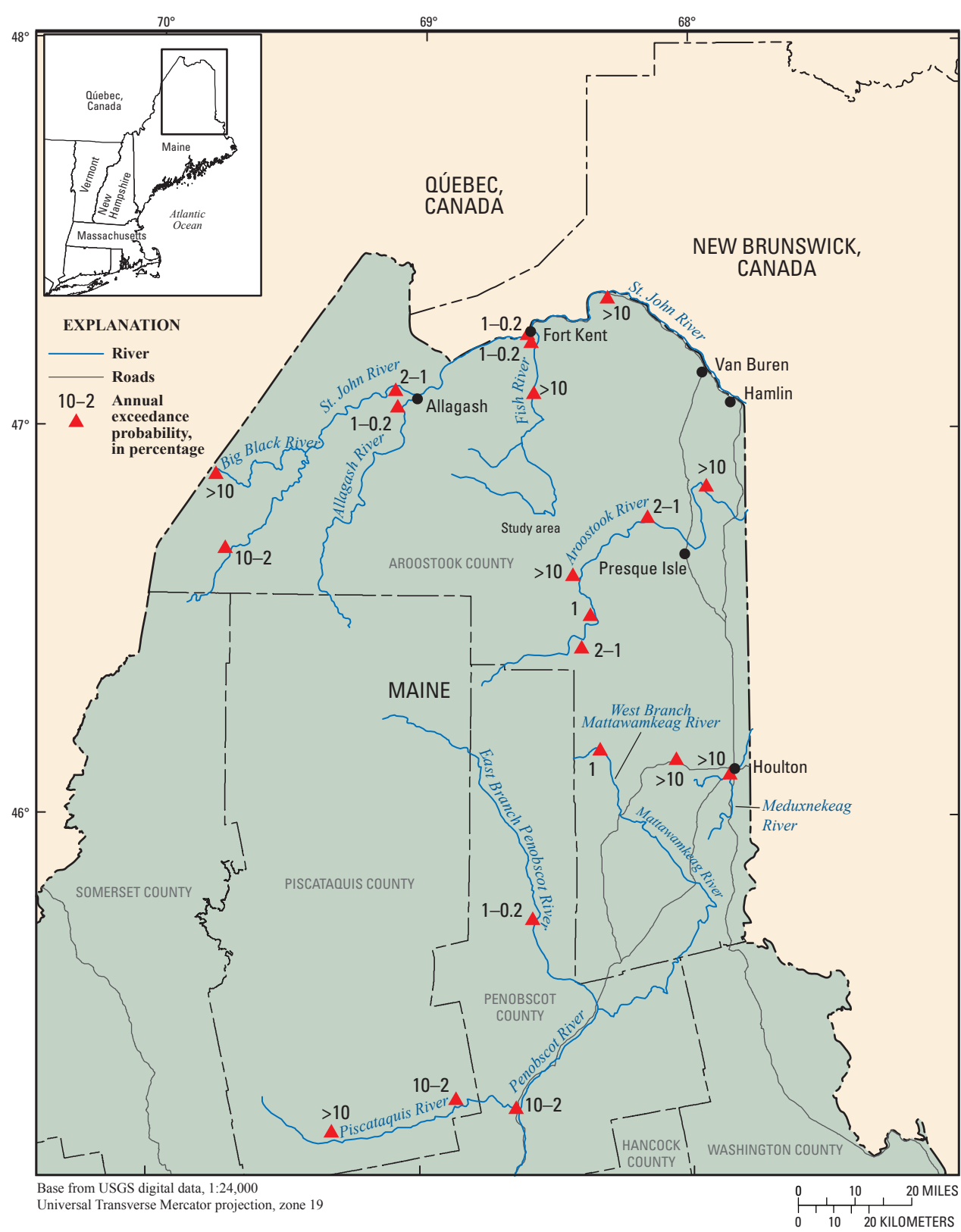

Figure 1. Peak streamflow exceedance probabilities associated with the spring 2008 flood in northern Maine.

\section{FLOOD-FREOUENCY TERMINOLOGY}

In past flood reports, flood frequencies were expressed as recurrence intervals for selected flood quantiles such as the "100-year flood." The use of recurrence-interval terminology is now discouraged by the U.S. Geological Survey because it sometimes causes confusion for the general public. Recurrence-interval terminology is sometimes interpreted to imply there is a set time interval between floods of a particular magnitude; however, floods are random processes that are best understood using probabilistic terms. The use of annual exceedance probability is now recommended because it conveys the probability, or odds, of a flood of a given magnitude being equaled or exceeded in any given year. The exceedance probability is equivalent to the reciprocal of the recurrence interval and is expressed as a percent. For example, a flood with an annual exceedance probability of 1 percent corresponds to a 100 -year flood. 